\title{
Academic talent: Perceived challenges to talent management in the South African higher education sector
}

\begin{tabular}{|c|c|}
\hline \multicolumn{2}{|c|}{$\begin{array}{l}\text { Authors: } \\
\text { Rhodrick N. Musakuro } \\
\text { Frances de Klerk }{ }^{1}\end{array}$} \\
\hline \multicolumn{2}{|c|}{$\begin{array}{l}\text { Affiliations: } \\
\text { 1Department of Human } \\
\text { Resources, Faculty of } \\
\text { Business and Management } \\
\text { Sciences, Cape Peninsula } \\
\text { University of Technology, } \\
\text { Cape Town, South Africa }\end{array}$} \\
\hline \multicolumn{2}{|c|}{$\begin{array}{l}\text { Corresponding author: } \\
\text { Rhodrick Musakuro, } \\
\text { rmusakuro@gmail.com }\end{array}$} \\
\hline \multicolumn{2}{|c|}{$\begin{array}{l}\text { Dates: } \\
\text { Received: } 07 \text { May } 2020 \\
\text { Accepted: } 27 \text { Oct. } 2020 \\
\text { Published: } 29 \text { Jan. } 2021\end{array}$} \\
\hline \multicolumn{2}{|c|}{$\begin{array}{l}\text { How to cite this article: } \\
\text { Musakuro, R.N., \& De Klerk, F. } \\
\text { (2021). Academic talent: } \\
\text { Perceived challenges to } \\
\text { talent management in } \\
\text { the South African higher } \\
\text { education sector. SA Journal } \\
\text { of Human Resource } \\
\text { Management/SA Tydskrif vir } \\
\text { Menslikehulpbronbestuur, } \\
\text { 19(0), a1394. https://doi. } \\
\text { org/10.4102/sajhrm. } \\
\text { v19i0.1394 }\end{array}$} \\
\hline \multicolumn{2}{|c|}{$\begin{array}{l}\text { Copyright: } \\
\text { ( 2021. The Authors. } \\
\text { Licensee: AOSIS. This } \\
\text { is licensed under the } \\
\text { Creative Commons } \\
\text { Attribution License. }\end{array}$} \\
\hline \multicolumn{2}{|l|}{ Read online: } \\
\hline 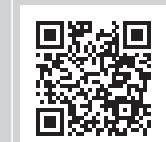 & $\begin{array}{l}\text { Scan this QR } \\
\text { code with your } \\
\text { smart phone or } \\
\text { mobile device } \\
\text { to read online. }\end{array}$ \\
\hline
\end{tabular}

Orientation: Talent management is one of the most important and key strategic issues facing managers in the South African (SA) higher education sector.

Research purpose: The study aimed to establish talent management challenges at one selected SA public higher education institution (HEI) which offers contact tuition in the Western Cape.

Motivation for the study: Emerging trends show talent management has since presented unique sets of challenges in the SA higher education sector. SA needs to attract and retain academic talent to reach target levels of education and skills development and also ensure tertiary institutions accomplish their visions and missions.

Research approach/design and method: We conducted the study using the interpretivist research paradigm. Semi-structured interviews were applied to a purposive sample of 7 human resource (HR) professionals from one selected HEI in the Western Cape. Content analysis was used for data analysis.

Main findings: We established that workforce planning, compensation and rewards, training and development, succession planning, recruitment, selection, and performance management were negatively affecting the talent management practices of the selected HEI.

Practical/managerial implications: HR professionals can use the study findings as a basis for understanding talent management challenges in a selected HEI and what causes these challenges.

Contribution/value-add: The study establishes an insight into the talent management challenges of a selected HEI and provides reasons for what causes them. It also made several recommendations to the institution in order to solve the talent management challenges.

Keywords: higher education institutions; talent; talent attraction; talent retention; talent management; South Africa.

\section{Introduction}

Talent management is one of the most important and key strategic issues that managers face in the modern-day business environment (Silzer \& Dowel, 2010). In the case of the higher education sector, there is a growing demand for academic staff in higher education institutions (HEIs) and the economic outlook predicts a further increase in the global demand (Theron, Barkhuizen, \& Du Plesis, 2014). On the other hand, retention problems are also a growing concern for management (HESA, 2011). Increased demand and retention concerns have since presented a unique set of challenges into the whole talent management system for management of HEIs. It appears that the so-called 'war for talent' is hugely affecting the higher education sector as predicted by previous scholars (Chambers, Foulon, Handfield-Jones, Hanklin, \& Michaels, 1998). Under such circumstances, academic talent will need to be managed more effectively and efficiently in HEIs. Effective and efficient talent management enables academic staff to improve productivity and could also help to increase job satisfaction.

\section{Research purpose and objectives}

This study seeks to establish the talent management challenges at one selected South African (SA) public HEI, which offers contact tuition in the Western Cape. It is expected that human resource 
(HR) professionals can use the findings as a basis for understanding talent management challenges in a selected HEI and what causes these challenges.

With the research purpose, several research objectives were identified for the literature review and empirical study. Firstly, the literature review aimed at conceptualising the theoretical aspects of talent management and understanding recent talent management trends in the higher education landscape. Secondly, the empirical study aimed at exploring challenges associated with talent management at one selected HEI. Thirdly, the study also aimed at understanding the causes of talent management at one selected HEI. Finally, it aimed at making recommendations to the selected HEI management to improve its talent management practices.

\section{Literature review Managing academic talent}

In SA's higher education sector, it is important to attract and retain academic staff because these are the employees who help to ensure that the visions and missions of the universities are achieved ( $\mathrm{Ng}^{\prime}$ ethe, Iravo, \& Namusonge, 2012). Moreover, the role of the academic staff is of paramount importance because they lead to economic growth, reduction of poverty and supply of scarce skills (CHE, 2008; HESA, 2011). It is also important to retain knowledgeable academic staff because of financial costs associated with losing them (Currie, 2006). If it can be agreed that talented employees bring about desirable success and sustainable development to universities, then losing them will cost the HEIs (Netswera, Rankhumise, \& Mavundla, 2005). Several scholars concur that costs such as costs of hiring new employees, training and development, induction and orientation programmes, turnover costs, disruptions of productivity, and declining morale, amongst others, can affect organisations severely (De Cieri et al., 2008; Pienaar \& Bester, 2008).

\section{Challenges in the South African higher education institutions}

The demand for academic staff in the HEIs has significantly increased and future projections suggest it is expected to increase (Theron et al., 2014). Reports suggest that more than half of the academics will be retiring in less than a decade from now and since then, there has been a concern on the supply of labour as the current academic pipeline is insufficient (HESA, 2011). The situation is further worsened by the fact that most HEIs have recorded a large increase in student enrolment in the last two decades (HESA, 2014a, 2014b). A number of factors are contributing to the shortage of academic staff in SA HEIs. Amongst these factors are resignations, dismissals, emigration of experienced academics for greener pastures and restrictions related to self-development and a lack of recognition for good performance (Adedeji \& Olaniyan, 2011; Schullion, 2011). In addition, a previous report found that poor remuneration and reward practices are some of the main factors contributing to reasons why the academic staff are leaving the HEIs (DBSA, 2010). A study by Theron et al. (2014) revealed that $34 \%$ of academic staffs were considering leaving their current institution because of unhappiness with their compensation and rewards. Another study at a SA HEI by Nkomentaba (2014) found that $63 \%$ of the respondents agreed that they would leave their HEI to earn more pay elsewhere. Consequently, SA academics are incompetently remunerated relative to other occupations in the public and private sector where the same qualifications, expertise and skills are required. Therefore, as a consequence, a significant reduction in the number of potential and capable academics from the private and public sector to tertiary institutions like universities and colleges was observed (DBSA, 2010). According to the South African Council of Educators (SACE) (2010), academics are leaving HEI for better compensation in developed countries or for other career opportunities. This turnover affects service delivery and has huge negative effects on the performance of the students (Williams, Champion, \& Hall, 2012).

Another talent management challenge in SA HEIs is related to funding. It has been reported that universities in sub-Saharan Africa are under-resourced (HESA, 2011). In the last two decades, state and research funding in universities has worsened (De Villiers \& Steyn, 2009). This means that universities are not able to invest adequately in the development of academics as funds are no longer sufficient (HESA, 2011). A major implication of underdevelopment of staff is the impact on the individuals' career motivation, career success and even employability of academics (Bitzer, 2008).

\section{Talent}

Silzer and Dowell (2010) explain that 'talent' refers to an individual's skills and abilities and this is what a person can contribute towards the success of the organisation. This suggests that employees with the 'talent' contribute and make an impact on the strategic aspects of the organisation. According to the Chartered Institute of Personnel Development (2006), 'talent' refers to a complex mixture of employees' skills, knowledge, cognitive ability, potential, values and work preferences. Cappelli (2008) describes 'talent' as those attributes of an employee that an individual carries such as knowledge, a powerful resource which they possess in fulfilling the mission of the organisation. Based on this information so far, it can be seen that the term 'talent' varies in the literature as some authors consider some aspects that make up 'talent' as more important, whilst others fail to include them at all. The connotation implies that no single definition fits all contexts as there are different views about the nature and definition of the term 'talent'. Therefore, for the purposes of this research study, 'talent' will be defined as a genetically coded assortment of skills, abilities, knowledge, experiences, values, intelligence, attitude, character, competence, commitment and 
contribution that are brought about to add towards the organisation's objectives.

\section{Talent management}

The history of talent management shows that the topic was made known globally since the McKinsey consultants' ground-breaking research study in 1997, which was followed by the 2001 publicised book 'The War for Talent' (Axelrod, Handfield-Jones, \& Michaels, 2002). Since then, the topic of talent management has gained significant attention globally in both practice and theory. This represents a paradigm shift from traditional HR-related sources of competitive advantage (Miller, Burke, \& Glick, 1998) and strategic HR management (Huselid, Jackson, \& Schuler, 1997) to management of talent relevant to today's changing competitive business environment (Van Zyl, Mathafena, \& Ras, 2017).

Talent management literature reveals a degree of debate as to the conceptual boundaries of the topic (Collings \& Mellahi, 2009). Defining talent management appears to be a challenging phenomenon for scholars (Lewis \& Heckman, 2006). This is because of different connotations, terms and conditions made by previous academics who wrote about the very same subject matter. Ashton and Morton (2005) state that there is no single consistent or concise definition of talent management. At the same time, it has been found that talent management has focused more on current organisational practices, but it often lacks a theoretical perspective (Al Ariss, Cascio, \& Paauwe, 2014). As there are no consistencies in the literature about the definition of talent management, this study will now consider various definitions of talent management.

From the above preliminary definitions of talent management in Table 1, it can be reiterated that there are no consistencies in defining talent management (Ashton \& Morton, 2005). Whilst defining talent management, it is also of paramount importance to define strategic talent management. According to Collings and Mellahi (2009), strategic talent management refers to a

[S]et of activities and processes that involve the systematic identification of key positions which differentially contribute to

TABLE 1: Definitions of talent management.

\begin{tabular}{ll}
\hline Definition & Source \\
\hline $\begin{array}{l}\text { The systematic planned strategic effort by an } \\
\text { organisation to attract, retain, develop and motivate } \\
\text { highly skilled employees and managers }\end{array}$ & $\begin{array}{l}\text { Noe, Hollenbeck, Gerthart } \\
\text { and Wright (2012) }\end{array}$ \\
$\begin{array}{l}\text { The use of an integrated set of activities ensures that the } \\
\text { organisation can attract, retain, motivate, and develop }\end{array}$ & Armstrong (2006) \\
the talented people it needs now and in the future & \\
$\begin{array}{l}\text { An automated end process of planning, recruiting, } \\
\text { developing, managing and compensating employees } \\
\text { throughout the organisation }\end{array}$ & Dessler et al. (2011) \\
$\begin{array}{l}\text { An integrated set of processes, programmes and } \\
\text { cultural norms in an organisation, which are designed } \\
\text { and implemented to attract, develop, deploy and retain } \\
\text { talent to achieve strategic objectives and meet future } \\
\text { business needs }\end{array}$ & Silzer and Dowel (2010) \\
$\begin{array}{l}\text { The anticipation of human capital needs into the future } \\
\text { and setting out a plan to meet them }\end{array}$ & Capelli (2008) \\
\hline
\end{tabular}

Source: Noe, Hollenbeck, Gerthart and Wright (2012); Armstrong (2006); Dessler, Barkhuizen Bezuidenhout, De Braine, Du Plessis, Nel, Stanz, Schultz and Van der Walt (2011); Silzer and Dowel (2010); Capelli (2008). the organisation's sustainable competitive advantage, the development of a talent pool of high potential and high performing incumbents to fill these roles, and the development of a differentiated human resource architecture to facilitate filling these positions with competent incumbents and to ensure their continued commitment to the organisation.

In this context, talent is seen as a valuable and scarce resource and organisations gain a competitive advantage when they develop their talent.

Silzer and Dowell (2010) are of the view that strategic talent management entails systems and processes that are driven and fully integrated with business and talent strategies. These should be managed as core business processes as they are strongly related and dependent on one another. To make strategic management a success, different people assume various roles as areas of responsibility and accountability in driving strategic talent management (Silzer \& Dowell, 2010, p. 57). These people include a board of directors, chief operating officer (CEO), senior executives, HR and talent professionals, line managers and individual employees who has the talent. However, HR practitioners are expected to take the lead in driving strategic talent management as full business partners to the $\mathrm{CEO}$ and other senior executives.

After considering the definitions of talent, talent management and strategic management, it can be said that talent management is associated with a mix and use of an integrated set of activities, functions and different processes implemented in a strategic way to achieve sustainable competitive advantage. Therefore, talent management focuses on ensuring that the right person is in the right job at the right time.

Key functions of talent management include talent planning, talent mobility, talent acquisition, talent development, managing talent and talent retention. Talent planning is the first critical step that an organisation takes towards successful talent management practices. It involves determining talent management processes and activities. Furthermore, it also consists of internal and external environmental analysis, business strategy, talent management strategy, talent success profile and workforce planning. Talent acquisition is a second key component of talent management, which focuses on finding and employing talent to ensure sufficient supply of talent in both the short term (operational) and long term (strategic) to meet business strategic goals. It consists of onboarding, induction, recruiting, selecting and employing talent. Talent development is the third component of talent management, which focuses on growing and developing talent to ensure the broad-based acquisition of knowledge, skills, experience and behaviours. To develop talent, organisations use several methods such as training, development, coaching, mentoring and career management. Managing talent is the fourth component of talent management. It follows that individual and group performance must be managed so that corrective action will be taken when and where necessary. Sub-components of 
managing talent include performance management, performance measurement, compensation and reward management. Finally, talent retention involves sets of activities that an employer combines, and when assembled, they result in the academic talent taking decisions to remain in the HEI for longer periods. Talent retention consists of a retention strategy and an employee value proposition (EVP) in order to effectively retain talent.

\section{Research method \\ Research design}

This study used a qualitative research method that involves the collection of data in the form of words (Brynard \& Hanekom, 2006). This method was chosen as it enables the collection of data, which is directly related to subjective personal experiences and hence, by nature, it is exploratory in its application (Flick, 2011). Precisely, this method was considered suitable as it provides useful insights into gaining an in-depth understanding of talent management practices at the selected SA HEI (Myers, 2013).

\section{Research philosophy}

This study adopted an interpretivist research paradigm (Walliman \& Baiche, 2001). The position of this study was ontological in nature as it studied talent management practices by exploring the challenges that a selected HEI is experiencing and what is causing these challenges at the selected HEI.

\section{Population and sample}

The sample is composed of seven HR professionals. The sample also has six HR business partners from five faculties and one talent management specialist from the Department of Human Capital. The sample was selected using purposive sampling because of which the researchers are considered to be typical relevant units from the population. The rationale for choosing the population of the HEI located in the Western Cape was to minimise the travelling expenses whilst benefiting on the ease of access to various faculties and departments of the selected HEI.

\section{Research instrument}

Primary qualitative data were collected using semi-structured individual interviews. This involved direct personal contact with seven HR professionals where a set of questions were asked about talent management practices. Each interview involved face to face interaction using an interview guide with 23 questions for each participant. On average, each interview lasted about $40 \mathrm{~min}$. Interview questions were drafted based on theoretical information from the literature. A rich picture emerged and helped in overcoming misinterpretations and misunderstandings of words and questions. Prior to data collection, a pilot study was conducted through face to face semi-structured interviews with two non-participants using an interview guide. Valuable comments and feedback were given to the researchers. Potential gaps that existed in the data collection instrument were exposed and made known to the researchers. Immediately, adjustments were made for the actual participants to ensure that questions asked for the study were relevant and participants interpreted them correctly.

\section{Data recording}

Interviews were tape-recorded and thereafter, the researchers transcribed the interview responses. This was aided with the support of field notes to support interview recordings, thus eliminating errors of omission.

\section{Data analysis}

The researchers followed the content analysis and thematic analysis approach to analyse the data collected (Long, 2014). This involved searching for phrases and words that appeared to be the same based on the literature on talent management. The main themes were identified, which led to the conclusion and recommendations. Content analysis allowed for data to be presented in words and themes and also allowed for easy interpretation of the results (Bengtsson, 2016). The thematic analysis enabled the meaning and interpretation of the data whereby the researchers allocated codes and assigned themes to the collected data (Neuendorf, 2019). The recorded and transcribed text was allocated appropriate labels, themes, codes and categories in alignment with the research objectives of the study (Bazeley, 2013).

As can be seen in Table 2, a majority of respondents were men (4) and females were three. The sample consisted of six participants of black people or African descendant and one participant of mixed-race descendant. Only one out of seven participants was a talent management specialist (participant 1) and all other participants were HR business

TABLE 2: Demographic profile of human resource professionals as participants.

\begin{tabular}{|c|c|c|c|c|}
\hline Participant & Gender & $\begin{array}{l}\text { Length of } \\
\text { service }\end{array}$ & Qualifications & Race \\
\hline 1. & Male & 1 year & $\begin{array}{l}\text { - MPhil: Labour law } \\
\text { - BTech: Human resource } \\
\text { management } \\
\text { - National diploma: Human } \\
\text { resource management }\end{array}$ & Black people \\
\hline 2. & Female & 9 years & $\begin{array}{l}\text { - National diploma: Personnel } \\
\text { management } \\
\text { - BCom: Industrial psychology } \\
\text { - National diploma: Office } \\
\text { management technology }\end{array}$ & Black people \\
\hline 3. & Male & 5 months & $\begin{array}{l}\text { - BCom: Human resource } \\
\text { management } \\
\text { - Postgraduate diploma in } \\
\text { labour law } \\
\text { - Currently studying BTech } \\
\text { human resource development }\end{array}$ & Black people \\
\hline 4. & Female & 9 years & - BCom Honours degree & Mixed race \\
\hline 5. & Male & 11 years & - MCom Industrial psychology & Black people \\
\hline 6. & Female & 3 years & $\begin{array}{l}\text { - BTech: Human resource } \\
\text { development }\end{array}$ & Black people \\
\hline 7. & Male & 3 years & $\begin{array}{l}\text { - National diploma: Human } \\
\text { resource management } \\
\text { - Further certificate: Human } \\
\text { resource management in } \\
\text { higher education }\end{array}$ & Black people \\
\hline
\end{tabular}


partners. Participant 3 was the participant with the shortest length of service, whilst participant 5 had the longest length of service. In terms of qualifications, two respondents had the highest level of qualifications (MPhil Labour Law and MCom Industrial Psychology), whilst others had postgraduate degrees, Honours degrees, BTech or National Diplomas in various courses as their highest qualifications.

Bearing in mind that the institution herein under investigation had six faculties, the researchers did not manage to interview one HR business partner in one of the faculties because of the unavailability of the potential participant who was on leave for a lengthy period during data collection. Then, acting HR business partner (potential participant) declined to be interviewed and cited lack of familiarisation and full understanding of the duties and responsibilities of the business partner.

\section{Ethical consideration}

This study followed appropriate ethical considerations that are morally acceptable as prescribed and recommended by Bless et al. 2006, p. 140; Brynard \& Hanekom 2006, p. 84). These included steps to ensure no one was affected during this study and no use of incentives both financial and nonfinancial benefits for participants. This research paid a large amount of attention to confidentiality issues and there was no discrimination of participants throughout this study. Also, consent letters were obtained and signed to survey participants. Furthermore, participants were informed of their rights during this study. It is equally important that the researchers conducted this study with integrity and transparency.

Before commencing this study, permission to conduct research was sought from the HEI whose talent management practices in the form of an introductory letter were investigated. The letter provided details pertaining to the background information of this study and research objectives. In turn, the researchers were provided with a consent letter stating permission approval to conduct research and this was issued by the person who controls research access at the higher education institution that was investigated. 2015FBREC288

\section{Findings and discussion \\ Theme 1: Talent planning}

\section{Sub-theme 1: Workforce planning}

Drawing from the participants' responses, three participants (participants 1, 2 and 6) pointed out that workforce planning is performed by the Institutional Planning Office using fulltime equivalent (FTE). They, in turn, advise Business Partners for each faculty and the entire Human Capital department on the execution of those plans. Notably, this finding differs from the discussion in the literature review where it was noted that the responsibility of workforce planning rests with HR practitioners who play a lead role in the whole process although they work with line managers (Warnich, Carrrell, Elbert, \& Hatfield, 2015). Van Zyl, Mathafena and Ras (2017) recommend many role players to be involved in the development, planning and implementation and improvement of talent management plans and that these should include line managers, talented employees, organisational leaders and HR practitioners. In contrast, two participants (participants 5 and 7) indicated that they were not aware of a formalised process and at the same time, they mentioned that the institution does not have a model. To be specific, participant 5 had this to say:

'I am not aware of a formalised process. Currently, it is done on an ad hoc basis ....'

'... However, this process is a challenge because if you look at the totality, we have funding problems, succession planning among others.'

Participant 7 mentioned another talent management challenge:

'... now there is no uniformity, it varies from department to department. Some departments are proactive to plan ahead. Some it's just filling in roles when a vacant position comes. So, we do not have a model we are failing with that regards ....'

Recapping from participants 5 to 7 , it appears that there is no uniformity and consistent application of practices in all the departments with regard to workforce planning and it is only performed for specific reasons from time to time. Another finding made in this study shows that majority of participants (five out of seven) indicated a major concern over the longterm planning and future direction of the HR needs of the institution. The consensus amongst the majority of participants (five out of seven) is that the institution is focusing on the current work only. Long-term planning appears to be difficult because of a lack of a permanent executive director to lead the Department of Human Capital. From a strategic management point of view, a lack of permanent executive director in the Department of Human Capital raises a major concern in terms of clarity and strategic direction of the institution. Therefore, in this context, the executive director of Human Capital forms part of the top management of the institution, which ought to be driving the process of strategic management.

The majority of participants (five out of seven) in this study indicated that the institution does not have a retention strategy to retain experienced workers. According to Bussin (2014), a retention strategy is important because it helps the organisation to achieve a sustainable competitive advantage in the context of talent attraction and talent retention. It also supports the organisation to align with its environment. However, these benefits appear to be challenging to attain because this study found that the organisation does not have a retention strategy. However, one participant (participant 1) mentioned that the organisation makes use of the EVP to retain employees, which include benefits, salary packages, promotion and others. Therefore, this finding is in line with the talent management literature in that designing a unique 
employer value proposition can support employer effort to retain employees (Bussin, 2014). Besides, two participants (participants 6 and 7) mentioned that the organisation provides training and development initiatives to retain experienced employees.

\section{Theme 2: Talent acquisition}

\section{Sub-theme 1: Recruitment and selection}

The majority of participants (six out of seven) indicated that the organisation follows the traditional approach to recruitment and selection. Also, three participants added that apart from using the traditional method, the organisation also makes use of headhunting. Participant 3 explained that:

'We are still using the traditional methods where we advertise, and we try to attract the best talent we can. It's just the normal recruitment and selection process where you go through the motion of firstly defining the job and finding out the minimum requirements and advertise it. It's not a contemporary approach, it's just a basic traditional approach ....'

Although some participants had concerns, the majority (six out of seven) indicated that the current method of identifying talent in the organisation is effective. The effectiveness as explained by the participants is that the methods of recruitment and selection enable key activities to be completed. More so, it was explained that the recruitment and selection process conform to the Labour Relations Act 66 of 1995 as explained by participant 6 :

'It is effective because it follows and conforms with Labour Relations legislation. It is also effective because we advertise positions in the right channels and people go through the selection process and we also make appointments ... .'

However, some participants explained that effectiveness depends on the discipline of the position to be filled like critical skills or general positions. This means that when a position is a critical skill, they explained that it usually takes more time to fill the vacant position when compared with a general academic staff position. Participant 5 explained that:

'It varies on the discipline for example in engineering countrywide it is a scarce skill. The few scarce skills that are there at the market are targeted by everyone. So, sometimes through these traditional ways of advertising sometimes you don't get the people, and, in that way, we don't have a targeted way of sourcing candidates where you go and source candidates and convince them to apply ....'

In terms of difficulties experienced when attracting new employees, participants 2 and 4 indicated that the institution encounters competitive industry remuneration packages that are higher than the institution's remuneration packages. This finding is in line with the literature. South African academics are incompetently remunerated relative to other occupations in the public and private sector where it requires the same qualifications, expertise and skills; as a result, it has led to a significant reduction in the number of potential and capable academics from the private and public sector to tertiary institutions such as universities and colleges (DBSA, 2010).
One participant (participant 2) indicated that one of the difficulties in talent management is the challenge related to the attainment of employment equity targets. Participant 2 elaborated further that:

'Its salaries. We are unable to match the industry remuneration packages, but the biggest issue is the employment equity targets. This is because we may attract, they may be available, they meet the minimum requirements but not necessarily addressing our employment equity targets.'

The above-explained finding is consistent with the results of Badat (2008) who made a similar finding. It was found that one of the challenges in HEIs is related to transformation and addressing imbalances of the past.

A previous research study shows a positive relationship between employer brand, talent attraction and talent retention (Botha, Bussin, \& De Swardt, 2011). However, in this study, three participants indicated concerns about the employer brand. Participant 5 indicated that the institution's brand is not fully known. At the same time, currently, it is being tarnished by the student protest actions. Precisely, participant 5 clarified that:

'... The brand itself of the institution I think it's not fully known out there. I think our brand is even getting tarnished by these students' protest actions.'

On the other hand, participants 3 and 7 mentioned that the current state of the institution and the ongoing student protest actions are negatively impacting the employer brand, particularly talent attraction. The negative effect as explained by the participants is that student's protest actions discourage prospective employees to join the institution.

Other difficulty and weakness that were found are that institution's recruitment and selection process is too lengthy. The time taken in filling academic positions is long because of the SENEX Committee, which meets once a month to discuss and make final decisions when making appointments. In support, four participants (participants 1, 2, 6 and 7) were all in accord that because of delays, some applicants end up not taking offers by the institution because of lack of patience as a result of the bureaucracy in the finalisation of recruitment and selection processes of the institution. Therefore, in terms of efficiency and being time-oriented in alignment within the context of talent management, it can be said that the institution is not efficient. Findings of this study contrast with the definition and business case for talent management where it was explained in the literature that talent management is all about ensuring that the right person is in the right job at the right time (Bussin, 2014). As a suggestion, participant 7 suggested a cut in the red tape to the recruitment and selection process to make the process more efficient. Recapitulating the findings, one of the respondents said:

'The other challenge is the time frame for filling in positions at this institution. It is too lengthy, the reason for that is because of different committees that seat and make final decisions when making appointments especially for academic positions. There is a committee called SENEX which meets once a month and if you 
miss the date you will have to wait for another date in the next month.' (Participant 1)

Another difficulty that was found includes the inability of the institution to attract local talent (SA citizens). This forces the institution to consider academics from foreign countries only if the position is a scarce skill.

It was also found that the institution is not fully embracing technology in its business operations and mostly working with the traditional approaches of paperwork. Furthermore, it was mentioned that, as a consequence, this has made it difficult to appeal to a younger generation when it comes to talent attraction. This finding of limited use of technology by the institution contrasts with the literature. According to Bussin (2014), Generation Y is made up of a cohort that is still young and falls somewhere between the 1980s and 2000. Also, this generation is technologically savvy, impatient, image-driven, adaptable, sceptical, efficient-multi-taskers and tolerant and can grasp new concepts. Therefore, it seems the institution is failing to fulfil these specific Generation $Y$ requirements.

In terms of strengths, the majority of participants (five out of seven) indicated that the institution's competitive salary packages including benefits are the main source of strengths in terms of its talent attraction. One participant (participant 2) explained further and indicated that the salary is competitive when compared with other provincial universities in the Western Cape. As discussed in the literature, compensation is the central point of connection between the employer and employees (Meyer \& Kirsten, 2005).

In addition to the above, other positive factors that were indicated include the reputation of the institution, research output and innovation of the institution. Some participants (participants 1, 5 and 7) indicated positively that these factors are helping to enhance talent attraction efforts of the institution. These findings are in line with the study results of Saurombe, Barkhuizen and Schutte (2017) who found that reputation and image of the higher learning institution are vital towards improving an institutional brand that can appeal to more academics. Reputation and image of higher learning institutions are regarded as key elements in the effective and efficient running of higher learning institutions.

\section{Theme 3: Managing talent}

\section{Sub-theme 1: Compensation and rewards}

In terms of compensation and rewards, the majority of participants (five out of seven) mentioned that salary is the main factor potential that employees would consider when deciding to be part of the institution. Three participants (participants 4,6 and 7) believe that potential employees would consider work benefits whilst two participants (participants 2 and 7) showed that some potential employees would consider conditions of service.
Other factors that were mentioned include geographical location, stability and growth opportunities within the institution. Findings of this study are in line with the research literature in that offering competitive salaries, growth opportunities, work benefits, conditions of service and geographic location all contribute towards talent attraction (Meyer \& Kirsten, 2005; Warnich et al., 2015). Interestingly, one participant (participant 1) believed factors that might be considered by potential employees vary from one generation to the other because of different career life stages and phases. Participant 1 had to say:

'It depends on the generation. For instance, an old professor would consider something completely different to a young lecturer who is new to the academic based on the generational gap. So, one cannot say these are the overall factors for all the employees. Therefore, it is important when the institution is looking at its value proposition in terms of compensation and rewards. They need to have a wide scale of things to consider so that each generation is catered for ....'

From participant 1 as mentioned above, this is exactly as noted in the literature that different generations have different generational needs and preferences concerning their career life stages (Van Zyl et al., 2017). Despite all the participants' feedback, participant 1 could not indicate any single factor and cited difficulties in coming up with factors because job advertisements do not include salaries and at the same time, no research has been carried out by the institution to find out why potential employees would want to join the institution. Therefore, because the institution has not put an effort into talent attraction factors, this indicates that the institution is 'relaxed' to put any effort into talent management practices.

The majority of participants (four out of seven) indicated that the institution's compensation packages both financial and non-financial rewards are effective and are contributing towards the retention of key employees. This positive finding contrasts with findings of previous studies that found that compensation was highly regarded as poor and unsatisfactory with the majority of participants (academics) considering quitting their profession because of their unhappiness (Theron et al., 2014).

Two participants (participants 2 and 5) mentioned that the institution is facing high and intense industry competition in terms of compensation and reward packages. Specifically, participant 2 had this to say:

'Industry competition. We require highly qualified individuals though we pay less when we are competing with the industry. For instance, if you look at the academics, in the industry they get more salary with a low level of qualification particularly to targeted groups and by this, I mean those that were previously disadvantaged.'

Participant 5 interestingly added that:

'We have no money. There are some challenges in the field like engineering and sciences. If you look at their salaries and see what the market offers you might find out that somebody with a 
BSc or National Diploma is getting more as compared to what we might be paying here and that causes problems to attract ....'

The above-mentioned findings are consistent with the findings by Developing Bank of Southern African that SA academics are incompetently remunerated relative to other occupations in the public and private sector where it requires the same qualifications, expertise and skills (DBSA, 2010). As a result, this has led to a significant reduction in the number of potential and capable academics from the private and public sectors to tertiary institutions.

Two participants (participants 6 and 7) indicated that the institution is experiencing financial constraints in compensation budgets in as far as attracting and retaining employees is concerned. This means that the institution is limited in talent attraction efforts to potential employees and this further constrains its talent retention efforts. The situation is further worsened by the fact that the organisation has too much red tape around the authorisation of salaries. In other words, it was found that the institution has an excessively long administrative procedure in decision-making that needs to be reviewed.

This study also found that the institution is not offering competitive salaries when compared with other nations in developed countries. Although the HEI is not competitive against foreign countries, this finding validates the finding of SACE (2010). They report that academics are leaving HEIs for better compensation in developed countries or for other career opportunities.

The majority of participants (six out of seven) indicated that compensation and reward packages are reviewed yearly. Three participants expanded their responses and said that wage negotiations include stakeholders such as the department of human capital, organised labour and executive management. This finding is consistent with the HESA (2014), which reported that in some SA HEIs, annual wage increases usually involve trade unions who play a role in the determination of academic salaries and type of benefits.

\section{Sub-theme 2: Performance management}

In terms of performance management, the participants did not disclose any positive feedback with regard to the performance management practices of the institution. They indicated several negative concerns. To begin with, participants 4 and 7 indicated that the institution does not have a formal performance management policy that guides the implementation of the process:

'We do not have a performance management policy, as previously indicated. The current one is not applied to all the employees. It is currently applied at the executive level and senior management.' (Participant 4)

'We are very weak in that area because at this stage even the performance management policy has not yet been adopted, it's still work in progress. The managers also do not know how to conduct performance management in their respective departments though there have been workshops arranged by the Learning and Development department to encourage the line managers to attend these workshops, still, these line managers do not attend.' (Participant 7)

However, the above-stated findings are inconsistent with the recommendation of the previous studies, which emphasised that application of the performance management system must be guided by a relevant institutional policy for managers and employees to know how to deal with performance and capability issues (Maimela \& Samuel, 2016).

Apart from the above findings, it was also found that there is limited implementation of performance management in the institution. Some participants indicated that it is implemented from grades 1 to 4 and some said that it is implemented from grades 1 to 6 ; yet, the institution has 18 grades and therefore, it was found that there is a partial implementation of the performance management system, which excludes a certain group of employees from the performance management processes. Some participants explained that performance management is only applied to the management level of the organisation. Specifically, participants 1, 2 and 3 had this to say:

'It is only implemented from grade 1 to 4 and it's not full implementation. Yet we have 18 grades. So, it's difficult to say something positive because it's not fully implemented ....' (Participant 1)

'The unions are saying no to performance management ... Senior management which is grade 1 to grade level 6 are forced to do it ... there are quite a lot of challenges and confusion. However, in my faculty, some people are doing it in some departments, but it is informal ... this current performance management process is not effective in the way it is handled at all.' (Participant 2)

'It's not something that is done on a regular basis, the only time I have seen it happening is during the probationary period ....' (Participant 3)

Another significant concern is that line managers do not have the knowledge and skills to conduct performance management. Although the participants indicated that line managers received training through workshops, it was found that that line managers are a weak link in the performance management of the institution. Perhaps, the training intervention was not sufficient and adequate as previously found by other scholars. In a study, Flaniken (2009) found that in most organisations, managers do not receive sufficient and adequate performance management training to equip and give them knowledge on how to rate employee performance. A previous study noted that the knowledge and ability of managers were satisfactory to enable the proper implementation of the performance management system. This was, however, contrary to the finding of this study.

Furthermore, it was found that there was non-uniformity in the application of performance management as some departments reported that they do not conduct performance management at all, whilst some departments do conduct. This finding is in line with the findings of Maimela and 
Samuel (2016). They report in their study that there was no consistent application of performance management by the organisation. Also, they argue that consistency in the application of performance management creates the integrity of the performance management system.

In terms of weaknesses, the involvement of organised labour emerged as the most frequently mentioned phenomenon amongst the participants. They mentioned that organised labour is completely against performance management practices. This has forced its members to resist and not support performance management practices. In a study, it was found that academics were not consulted during the design and implementation of the performance management process and this posed as a threat to the success of the performance management at the HEI (Aguinis, 2013). Recapitulating the findings, participant 4 and 6 had this to say:

'Unions have not agreed to subject staff to performance management. So thus far it is not enforced on staff, but it is encouraged for developmental purpose.' (Participant 4)

'It is not standardised and not everyone is doing it in accordance with the line managers and HR expectations. Some employees resist doing it especially those employees that belong to the trade union whose trade union does not support performance management processes.' (Participant 6)

\section{Theme 4: Talent development \\ Sub-theme 1: Training and development}

The overall remark that can be made on training and development theme is that majority of participants (six out of seven) indicated that they do not do anything regarding training and development. The participants mentioned that the institution has a separate department (Learning and Development Department), which specialises on that and the full responsibility lies with them and not the human capital department where the sample group of this study was drawn from:

'Training and Development is not done by Human Capital.' (Participant 1)

'As Business Partners we are just partially involved. The full responsibility lies with the Learning and Development Department.' (Participant 2)

'I do not do anything related to Training and Development.' (Participant 3)

'... can we skip any questions relating to training and development because my information is very limited ... ?' (Participant 6)

'We do not have any input as Business Partners when it comes to Training and Development.' (Participant 7)

Despite the above responses from the participants, some participants attempted to answer some questions during the interviews. Participants were asked about their opinion on whether their institution is providing enough resources and guidance to support the training and development of its staff. In this question, three participants (participants 1, 4 and 6) indicated that they were not sure because they do not do anything regarding training and development. Two participants (participants 2 and 7) positively indicated several ways in which the institution does support staff development. Firstly, they mentioned that it is through mandatory Teaching and Development Programme (TDP) for new staff. Secondly, staff development is supported by internal communications via Newsflash where all the training opportunities available are made known to the staff so that they can enrol. Finally, it was also indicated that the institution does support the training and development of staff through the Fundani Department and other units for academic support that organise conferences and workshops from time to time for academic staff to attend.

However, two participants (participants 3 and 5) highlighted several negative issues regarding the provision of resources and guidance to support the training and development of its staff:

'No, we are not because where I am from, induction is done immediately when you start, and here I haven't been inducted and I have been here for five months already, so you can imagine. Also, the fact that the Learning and Development department only has 3 employees for such a big organisation, as a learning organisation ....' (Participant 3)

'... they are not enough because of financial constraints. It's not that we don't have money as a university but it's a situation being experienced in the higher education sector now.' (Participant 5)

Based on the above responses, participant 3 mentioned two issues about the support of the training and development of institutional staff. The first issue mentioned involved issues that induction is conducted later than the generally expected time by new employees. Therefore, it appears that the institution is not efficient enough with regard to accommodating and assimilating through putting together employees into the organisational culture, processes, systems and methods. Poor induction programmes may be because of a lack of enough time to conduct an induction programme and a lack of responsibilities (Banfield \& Kay, 2012). Because the institution delays conducting induction programmes, it appears that they are missing out on the benefits of induction, which can enable employees to quickly settle and adapt in the institution and allowing them to reach full working capacity (Derven, 2008). The second issue that was mentioned was that the Learning and Development department is understaffed to operate effectively as a learning institution because it is a big organisation. In addition to participant 3 's response, participant 5 stated that the institution is not providing enough resources to support training and development mainly because of financial constraints. Participant 5 had this to say:

'... they are not enough because of financial constraints. It's not that we don't have money as a university but it's a situation being experienced in the higher education sector now.'

Participant 5 went further and stated that issues of being under-resourced are being experienced in the higher education sector currently. This is exactly as previously noted 
in the literature that HEIs are facing challenges related to funding. Precisely, universities in sub-Saharan Africa are under-resourced (HESA, 2011). State and research funding in universities has worsened in the last two decades, (Mouton, 2010). This means that universities are not able to invest adequately in the development of academics as funds are no longer sufficient.

\section{Sub-theme 2: Succession planning}

In terms of succession planning, three participants (participants 1, 5 and 7) indicated that the institution makes use of external programmes, that is, Khula and New Generation of Academics Programmes. These programmes are initiatives of the Department of Higher Education and Training (DHET), which seeks to bring in new highly capable scholars as academics by replacing retiring academic staff (DHET, 2018). Although these are current programmes to address succession planning, three participants (participants 2,3 and 6) mentioned that succession planning is not happening at all because the institution does not have their internal succession planning programmes. In other words, the participants indicated that the organisation does not have a succession planning system in place. The idea of succession planning is all about having a systematic process that helps to ensure that the organisation can assess and develop its employees to improve performance (Kim, 2003). A succession planning strategy entails designing a framework tool for purposes of determining potential replacement of senior members of the organisation (Schreuder \& Coetzee, 2011). In doing so, succession planning helps to facilitate transition when a senior member leaves the organisation and helps in the development of high potential employees. Therefore, based on the findings of this study, it appears that the institution is doing little to help with succession planning by using external programmes to address succession planning challenges. The situation is further worsened by the fact that the institution does not have a succession planning policy to guide the practices of succession planning. This has become the root cause of the challenges of any form of succession planning practices at the institution.

The participants indicated that the institution is facing replacement challenges when senior employees leave the institution. This is because the institution is not ready in most cases to fill the positions left by senior members of the institution. To be specific, participant 1 had this to say:

'We don't have succession planning policy or structured plan for the institution hence we heavily rely on those two programmes, Khula, and New Generation of Academics programmes as I have mentioned earlier.'

Another participant (participant 3) had this to say:

'The main challenge is that we don't have it at all. That's why we end up having problems when people retire because we end up not having people to fill their positions ....'

In addition to that, participant number 4 had this to say:

'We do not have a succession plan.'
Participant 5 went further detailed that:

'Like I said earlier, there is limited funding, no succession planning guidelines and there is limited number of applicants that can match the number of academic staff leaving mostly through retirements.'

Similar to participant 3, participant 6 further explained that:

'The fact that succession planning not happening means that we find ourselves with vacant positions at the time the person retires, and so we end up putting in contract workers to fill in positions, and in most cases, these vacant positions take longer time to fill them up.'

Similar to participants 1, 3, 4, 5 and 6, participant 7 went further and had this to say:

'Firstly, we do not have a policy document on succession planning that is a challenge as we do not have a guide. Secondly, from the departments' side, they do not look at the long-term view in as far as replacing people is concerned ....'

The findings of this study illustrate that the institution is not fully embracing succession planning adequately. This poses as a risk in their talent management practices because the institution seems to be finding it challenging in having the right employees in the right jobs at the right time with far much bigger challenges in winning the 'war for talent' in today's competitive times.

The majority of participants (five out of seven) positively indicated that the institution has the right set of employees to fill possible future vacancies. However, appointments in HEIs are mainly based on academic skills such as teaching and research skills and not leadership and people management skills (HESA, 2009).

Some participants indicated that although there are potential employees to replace and fill possible future vacancies, the participants indicated that a lot of training intervention still needs to be prepared to fully prepare potential talent for future roles. However, despite agreeing, it seems that there are challenges related to the fairness in the application of succession planning programmes like the Khula and New Generation of Academics programmes. This finding was found to be consistent with the findings of Bitzer (2008) who reported an inconsistent application of promotion policies in HEIs with the potential risk of deteriorating the profession of academics. Therefore, the view that organised labour finds succession planning practices as favouritism can be accepted. Specifically, participant number 7 had this to say:

'... We also have a challenge with organised labour. They consider it as favoritism if one is identified in a department. However, it doesn't help the organisation. They need to have a good understanding of the concept and how it adds value on the bigger picture.'

The majority of participants (five out of seven) indicated that there has not been any success with regard to succession planning practices at the institution. Three participants mentioned that success is limited as the funds for the Khula 
and New Generation of Academics programmes are not sufficient for all the departments. Because of the lack of funds, the participants had concerns over the rate at which succession planning programmes (Khula and New Generation of Academics programmes) are taking place. The programme's intake is very small because of financial constraints as they are externally funded. In a report, HESA (2011) mentions that government budget allocations and funding are not sufficient to fully subsidise higher education and training. This has made an impact on staff and student development. The major implications of the underdevelopment of staff are that they have an impact on the individuals' career motivation, career success and even employability of academics (Budderberg-Fischer, Stamm, \& Budderberg, 2009).

\section{Implication for application}

In terms of workforce planning, the institution needs to fill the vacant position with an experienced, competent and knowledgeable permanent executive director for Human Capital. Furthermore, this study recommends that the responsibility for workforce planning needs to be led by HR professionals. These HR professionals need to interact with line management from various departments to ensure consistency.

The institution needs to explore new ways to compensate and reward employees by customising compensation and rewards. In doing so, they need to take cognisant of different generational needs and preferences concerning their career life stages. In addition, there is a need to decentralise power to ease negotiations between HR professionals and prospective applicants. Moreover, the HEI needs to establish a remuneration committee that can look further into various efficient and effective ways to improve remuneration aspects of academics at the institution.

The HEI needs to introduce an internal succession planning system to facilitate the transition when senior members are leaving the institution. Also, the HEI should develop a succession planning policy that will provide guidelines in the practices and implementation of the succession planning system. To ensure the success of succession planning, management should engage with organised labour and the academic staff for consultations and obtaining their buy-in on the idea of succession planning.

To improve recruitment and selection, the institution needs to form strategic sourcing through building alliances and partnerships with various external sources that can supply talent in line with the future requirements of the institution. Furthermore, more meetings should be scheduled more than once per month for the SENEX Committee to make recruitment and selection processes more efficient. In the same vein, the institution needs to create a conducive and stable environment to facilitate the learning and growth of individuals.
In terms of training and development, the HEI should increase the number of staff in the Learning and Development Department. This will help to ensure efficiency and effectiveness in service delivery support such as employee induction.

This study recommends the institution to implement a formal and structured performance management system for academic staff from grades 1 to 9 in all the departments of various faculties in order to manage talent effectively. To do so, there is a need for the HEI to develop a performance management policy with peculiarities of the HEI and not the private sector. Furthermore, line managers need to be training on how to conduct performance management to their staff. For effective results, management should engage with organised labour and the academic staff for consultations and obtaining their buy-in on the idea of performance management before implementation.

The preceding recommendations have an impact on the attraction and retention of talent. The institution should, however, fit all these recommendations through developing a compelling EVP. A compelling EVP should outweigh the significant value of, for example, performance management alone. This recommendation affirms the view that a compelling EVP assists in identifying policies, processes and programmes that an institution can benefit from. The appointment of an executive director for Human Capital should spearhead the development and implementation of a retention strategy. A retention strategy should ensure that an institution can attract and retain talent. An effective retention strategy should be underpinned by fundamental policies, practices and structures that support the idea of retaining valuable employees within the institution.

\section{Conclusion}

This study sought to establish talent management challenges at one selected SA public HEI offering contact tuition in the Western Cape. Challenges associated with talent management practices and their causes at the selected HEI were identified. The challenges identified were negatively affecting the talent management practices of the selected HEI. In conclusion, it was established that talent management challenges linked to workforce planning are lack of uniformity and consistent application of workforce planning practises in all the departments. These challenges are caused by a lack of a permanent executive director to lead the department of Human Capital, lack of long-term planning goals and the absence of a retention strategy to retain experienced employees.

In terms of compensation and rewards, it was established that the institution is facing high and intense industry competition in terms of compensation and reward packages. Also, the institution has financial constraints in compensation budgets, which limits talent attraction and retention efforts of the employer. These challenges are caused by the red tape around the authorisation of salaries. Furthermore, the institution is not offering competitive salaries when compared to developed countries or the private sector. 
This study also established that succession planning is a talent management issue at the HEIs as the institution is facing replacement challenges left by senior employees when they leave the institution. Furthermore, major challenges that are faced in Khula and New Generation of Academics programmes were fairness in their implementation, strong resistance from organised labour and lack of sufficient funding for the programmes. The main cause of talent management challenges linked to succession planning is that the institution does not have a succession planning system as an alternative; the institution is making use of external programmes of Khula and New Generation of Academics programmes. Moreover, the institution does not have a succession planning policy to guide the practices of succession planning.

This study established that recruitment and selection is a talent management challenge at the selected HEI. The current student protest actions are tarnishing the institution's brand. The institution also finds it difficult and challenging to attain employment equity targets and to attract South African citizens. Moreover, the institution's recruitment and selection processes are too lengthy. The institution is finding it difficult to attract a younger generation. The current organisational culture is not conducive to a certain category of potential employees and it is discouraging them to join the institution. These talent management challenges linked to recruitment and selection are caused by the fact that the time taken in filling academic positions is too lengthy because of SENEX Committee, which meets once a month to discuss and make final decisions when making appointments. Also, the fact that the institution is not fully embracing technology has made it difficult to attract a younger generation.

Although the participants did not provide more details into training and development because of the fact that they do not perform any functions related to training and development, it was noted that training and development at the institution lack efficiency and effectiveness. This is caused by the fact that the Learning and Development Department is understaffed.

In terms of performance management, this study concludes that line managers at the HEI do not have full knowledge and skills to conduct performance management. There is no uniformity in the implementation of performance management processes as some departments do not conduct performance management at all, whilst some departments do conduct. Organised labour and their members are not supporting performance management practises. Therefore, this study concludes that the causes of poor performance management practices are because of limited implementation of performance management at the institution. Also, performance management is only implemented at the top management level (Grades 1 to 6) of the institution. Furthermore, the institution does not have a formal performance management policy that should guide the practices of performance management. Finally, line managers' training intervention was not sufficient and adequate to equip and give them the knowledge on how to conduct performance practices.
The recommendations proposed that, if they are to be implemented to a different HEI, they need to be customised to suit the requirements and aims of the HEI. The results contribute and are valuable as they represent an assessment of the current talent management practices at the HEI and could be used as a baseline for future improvements. The primary data collected from the university could be meaningful to the institution itself, whilst the generalisation of the results to other institutions could benefit institutions of higher learning in general.

\section{Limitations and recommendations}

Owing to low qualitative research participants and the fact that one HEI was investigated, research findings of this study are limited to certain faculties and departments. Therefore, the researchers suggest that the recommendations proposed that, if they are to be implemented to a different HEI, they need to be customised to suit the requirements and aims of the HEI.

Data collection of this study was conducted at a time when most HEIs in SA, including the institution investigated, were undergoing several student protest actions. Preferably, it would have been more conducive if the study was carried out in a more academically friendly and stable environment.

We recommend that future research of this nature should include other HEIs outside of the Western Cape and could utilise a quantitative approach to reach a larger sample of the population.

\section{Acknowledgements}

The authors would like to thank their friends and colleagues for the encouragement and support throughout this study.

\section{Competing interests}

The authors declare that they have no competing interest.

\section{Authors' contributions}

R.N.M. undertook this research study under the supervision of F.d.K.

\section{Funding information}

This research received no specific grant from any funding agency in the public, commercial or not-for-profit sectors.

\section{Data availability statement}

Data sharing is not applicable to this article as no new data were created or analysed in this study.

\section{Disclaimer}

The views and opinions expressed in this article are those of the author and do not necessarily reflect the official policy or position of any affiliated agency of the authors. 


\section{References}

Adedeji, S.O., \& Olaniyan, O. (2011). Improving the conditions of teachers and teaching in rural schools across African countries. Addis Ababa: United nations educational, scientific and cultural organization.

Aguinis, H. (2013). Performance management (2nd edn.). Upper Saddle River, NJ: Pearson Prentice Hall.

Al Ariss, A., Cascio, W.F., \& Paauwe, J. (2014). Talent management: Current theories and future research directions. Journal of World Business, 49(2), 173-179. https:// doi.org/10.1016/j.jwb.2013.11.001

Armstrong, M. (2006). A handbook of human resources management in practice (10th edn.). London: Kogan Page Limited.

Ashton, C., \& Morton, L. (2005). Managing talent for competitive advantage: Taking a systemic approach to talent management. Strategic HR Review, 4(5), 28-31. https://doi.org/10.1108/14754390580000819

Axelrod, B., Handfield-Jones, H., \& Michaels, E. (2002). A new game plan for C players Harvard Business Review, 80(1), 80-90.

Badat, S. (2008). Producing, transforming the social composition of and retaining a new generation of academics: The Rhodes University programme of accelerated development. Paper presented at the University Leaders Forum: Developing an retaining the next generation of academics, 24 November 2008, Accra, Ghana.

Banfield, P., \& Kay, R. (2012). Introduction to Human Resource Management (2nd edn.). New York, NY: Oxford University Press.

Bazeley, P. (2013). Qualitative data analysis: Practical strategies. London: Sage.

Bengtsson, M. (2016). How to plan and perform a qualitative study using conten analysis. Nursing Plus Open, 2, 8-14. https://doi.org/10.1016/j.npls.2016.01.001

Bitzer, E.M. (2008). The professoriate in South Africa: Potentially risking status inflation. South African Journal of Higher Education, 22, 265-281. https://doi. org/10.4314/sajhe.v22i2.25785

Bless, C., Higson-Smith, C., \& Kagee, A. (2006). Fundamentals of social research methods: an African perspective (4th edn.). Lusaka: Juta.

Botha, A., Bussin, M., \& De Swardt, L. (2011). An employer brand predictive model for talent attraction and retention. SA Journal of Human Resource Management, 9(1) 1-12. https://doi.org/10.4102/sajhrm.v9i1.388

Brynard, P.A., \& Hanekom, S.X. (2006). Introduction to research in management Related fields. Pretoria: Van Schaik publishers.

Buddeberg-Fischer, B., Stamm M. \& Buddeberg, C. (2009). Academic career in medicine - Requirements and conditions for successful advancement in Switzerland. BMC Health Serv Res, 9(70), 1-14.

Bussin, M. (2014). Remuneration and talent management: Strategic compensation approaches for attracting, retaining and engaging talent. Randburg: Knowres Publishing.

Cappelli, P. (2008). Talent on demand: Managing talent in an age of uncertainty. Boston, MA: Harvard Business School Press.

Chambers, E.G., Foulon, M., Handfield-Jones, H., Hanklin, S.M., \& Michaels, E.G. (1998). The war for talent. The McKinsey Quarterly, 1(3), 44-58.

Chartered Institute of Personnel and Development. (2006). Talent management: Understanding the dimensions. Retrieved from http://www.cipd.co.uk/ onlineinfodcouments

Collings, D.G., \& Mellahi, K. (2009). Strategic talent management: A review and research agenda. Human Resources Management Review, 19(4), 304-313. https://doi.org/10.1016/j.hrmr.2009.04.001

Council on Higher Education. (2008). The state of higher education in South Africa. Pretoria: Council on Higher Education.

Currie, D. (2006). Introduction to human resource management: A guide to personnel in practice. London: Chartered Institute of Personnel Development.

De Cieri, H., Kramar, R., Noe, R.A., Hollenbeck, J.R., Gerhart, B., \& Wright, P.M. (2008) Human resource management in Australia (3rd edn.). Sydney: McGraw Hill.

Department of Higher Education and Training. (2018). The new generation of academics programme. Retrieved from http://www.ssauf.dhet.gov.za/ngap.html

Derven, M. (2008). Management onboarding. Journal of Training and Development, $49-52$.

Dessler, G., Barkhuizen, N., Bezuidenhout, N., De Braine, R., Du Plessis, Y., Nel, P., .. Van Der Walt, H. (2011). Human resources management: Global and Southern African perspectives. Cape Town: Pearson.

Developing Bank of Southern Africa. (2010). The challenges of transformation in higher education and training institutions in South Africa. Retrieved from http:// www.dbsa.org/en/About-Us/Publications/Documents/The $\% 20$ challenges $\% 20$ of $\% 20$ transformation $\% 20$ in $\% 2$ higher $\% 20$ education $\% 20$ and $\% 20$ training $\% 20$ institutions $\% 20$ in $\% 20$ South $\% 20$ Africa $\% 20$ by $\% 20$ Saleem $\% 20$ Badat.pdf

De Villiers, A.P. \& Steyn, A.G.W. (2009). Effect of changes in state funding of higher education on higher education output in South Africa: 1986-2007. South African Journal of Higher Education, 23(1), 43-68.

Flaniken, F.W. (2009). Performance appraisal systems in higher education: An exploration of Christian institutions. Unpublished doctoral thesis. Orlando, FL: University of Central Florida.

Flick, U. (2011). Introducing research methodology: A beginner's guide to doing a research project. London: Sage.
Higher Education South Africa. (2009). First among equals: Stories from higher education leaders in South Africa. Pretoria: University of South Africa.

Higher Education South Africa. (2011). A generation of growth: Proposal for a national programme to develop the next generation of academics for South African higher education. Pretoria: University of South Africa.

Higher Education South Africa. (2014a). Remuneration of academic staff at South African universities: A summary report of the HESA statistical study of academic remuneration. Pretoria: Council On Higher Education.

Higher Education South Africa. (2014b). South African Higher Education in the 20th year of Democracy: Context, achievements and key challenges. Pretoria: Higher Education South Africa.

Huselid, M.A., Jackson, S.E., \& Schuler, R.S. (1997). Technical and strategic human resource management effectiveness determinates of firm performance. Academ of Management Journal, 40, 171-188. https://doi.org/10.2307/257025

Kim, S. (2003). Linking employee assessments to succession planning. Public Personnel Management, 32(4), 533-547. https://doi.org/10.1177/009102600303200405

Lewis, R.E., \& Heckman, R.J. (2006). Talent management: A critical review. Human Resource Management Review, 16(2), 139-154. https://doi.org/10.1016/j.hrmr. 2006.03.001

Long, H. (2014). An empirical review of research methodologies and methods in creativity studies (2003-2012). Creativity Research Journal, 26(4), 427-438. https://doi.org/10.1080/10400419.2014.961781

Maimela, E.M., \& Samuel, M.O. (2016). Perception of performance management system by academic staff in an open distance learning higher education environment. SA Journal of Human Resource Management, 14(1), 1-11. https:// doi.org/10.4102/sajhrm.v14i1.784

Meyer, M., \& Kirstern, M. (2005). Introduction to human resource management. Cape Town: New Africa Education.

Miller, C.C., Burke, L.M., \& Glick, W.H. (1998). Cognitive diversity among upperechelon executives: implications for strategic decision processes. Strategic Management Journal, 19/1) 39-58, https://doi.org/10.1002/(SICI)1097-0266 (199801)19:1\%3C39::AID-SMJ932\%3E3.0.CO;2-A

Mouton, J. (2010). African experience with collaborative graduate programmes. Research report. Stellenbosch: University of Stellenbosch.

Myers, M.D. (2013). Qualitative research in business \& management (2nd edn.) London: Sage.

Netswera, F.G., Rankhumise, E.M., \& Mavundla, T.R. (2005). Employee retention factors for South African higher education institutions: A case study. SA Journal of Human Resource Management, 3(2), 36-40. https://doi.org/10.4102/sajhrm. v3i2.64

Neuendorf, K.A. (2019). Content analysis and thematic analysis. In P. Brough (Ed.), Research methods for applied psychologists: Design, analysis and reporting (pp. 211-223). New York, NY: Routledge.

Ng'ethe, J.M., Iravo, M.E., \& Namusonge, G.S. (2012). Determinants of staff retention in public universities in Kenya: Empirical review. International Journal of Humanities and Social Science, 2(13), 105-212.

Nkomentaba, M.A. (2014). Talent retention in a further education and training (FET) college in Cape Town: a case study. Unpublished thesis. Cape Town: Cape Peninsula University of Technology.

Noe, R.A., Hollenbeck, J.R., Gerhart, B., \& Wright, P.M. (2012). Human resource management: Gaining a Competitive. New York, NY: McGraw-Hill.

Pienaar, C., \& Bester, C.L. (2008). The retention of academics in the early career phase: Empirical research. SA Journal of Human Resource Management, 6(2), 32-41. https://doi.org/10.4102/sajhrm.v6i2.171

Saurombe, M., Barkhuizen, E.N., \& Schutte, N.E. (2017). Management perceptions of a higher educational brand for the attraction of talented academic staff. SA Journal of Human Resource Management, 15(1), 1-10. https://doi.org/10.4102/ sajhrm.v15i0.831

Schreuder, D., \& Coetzee, M. (2011). Careers: An organisational perspective. Cape Town: Juta.

Schullion, H. (2011). Global talent management. New York, NY: Taylor \& Francis.

Silzer, R., \& Dowell, B.E. (2010). Strategy-driven talent management: A leadership imperative. San Francisco, CA: Jossey Bass.

South African Council for Educators. (2010). A review of teacher demand and supply: Identifying research gaps and the role of SACE. Pretoria: South African Council fo Educators.

Theron, M., Barkhuizen, N., \& Du Plessis, Y. (2014). Managing the academic talen void: Investigating factors in academic turnover and retention in South Africa. SA Journal of Industrial Psychology, 40(1), 1-14. https://doi.org/10.4102/sajip. v40i1.1117

Van Zyl, E.S., Mathafena, R.B., \& Ras, J. (2017). The development of a talent management framework for the private sector. SA Journal of Human Resource Management, 15(1), 1-19. https://doi.org/10.4102/sajhrm.v15i0.820

Walliman, N., \& Baiche, B. (2001). Your research project: A step-by-step guide for the first-time researcher. London: Sage.

Warnich, S., Carrrell, M., Elbert, N.F. \& Hatfield, R.D. (2015). Human Resource Management in South Africa (5th edn.). London: Cengage Learning.

Williams, C., Champion, T., \& Hall, I. (2012). MGMT. Toronto: Nelson Education Ltd. 